\title{
What could a UK REIT mean for UK hotels?
}

Received (in revised form): 14 October 2005

\section{Ros Rowe}

is a tax partner in the real estate tax practice of PricewaterhouseCoopers, specialising in the provision of property taxation. She has a broad spectrum of clients, ranging from owner-occupiers to those with interests in property investment and development through to PFI and urban regeneration. She is a member of the taxation policy panel of the Royal Institution of Chartered Surveyors and a board member of the Investment Property Forum. She is currently a member of a working party established jointly with the Treasury and the UK property industry to resolve some technical issues on REITs.

\begin{abstract}
The paper provides an update on how the government's thinking has evolved on the REIT model since it first sought consultation in March 2004. An explanation of the current requirements for REIT status is provided, together with a commentary on some aspects which still need to be resolved. Consideration is then given to the possibilities for investing in hotels, including reference to models in other tax jurisdictions. Readers will gain an insight into how REITs could be developed to facilitate investment in UK hotels where further changes are required to create an effective framework.
\end{abstract}

\section{Keywords:}

REIT, PIF, hotel, investment, real estate

\section{INTRODUCTION}

Hopes rose in the spring of 2005 that there would be a definitive announcement on Budget Day that a real estate investment trust (REIT) would be introduced (Table 1). As of this writing, however, it is not known if the UK government will join the REIT club, whose membership is extensive and no longer exclusive.

Table I: What is a REIT?

Ros Rowe

PricewaterhouseCoopers LLP

Southwark Towers

32 London Bridge Street

London SE1 9SY, UK

Tel: +44 (o) 2072135455

Fax: +44 (o) 2072125452

E-mail: rosalind.rowe@uk.pwc.com
Common characteristics

- REITs exist in many jurisdictions (eg the USA, Canada, Asia, Europe and Australia) with a number of common characteristics.

- A REIT enables investors of different tax status (taxpaying and non-taxpaying) to invest alongside each other.

- Generally, the vehicle suffers little or no tax so returns for non-taxpayers closely mirror direct investment.

- Investors get access to a greater pool of properties and therefore a greater spread of risk.

- REITs are used to invest in land-related assets (eg freehold/leasehold interests in land/buildings such as hotels, real-estate-backed mortgages, derivatives etc)

- Most REITs are owned by a designated minimum number of shareholders and are often listed (but not always) on a stock exchange.

- Some regimes (eg the USA) permit taxable subsidiaries, that is companies owned by a REIT which pay full tax on their income.

- They are usually structured to be effectively tax transparent:

- the REIT does not pay tax if it meets certain conditions

- instead, REIT investors receive distributions that are subject to tax only if the investor is a taxpayer. 


\section{Early difficulties}

\section{Signs of progress}

\section{DEVELOPMENTS TO DATE}

There have been some changes since the government put forward its first set of proposals for a new property investment vehicle in 2004. At that time the UK government initiated a debate on a new type of property investment vehicle which would be called a property investment fund (PIF, see Table 2). ${ }^{1}$

But there were a number of fundamental difficulties with the PIF. There were concerns about the level of the conversion charge (a levy made on a company to permit its 'conversion' to a REIT) and the proposed taxation of capital distributions as income. Also hotels and golf courses would be specifically excluded from being qualifying investments. It also appeared that the government wanted to control commercial factors such as gearing and management. Finally, the market did not like the government's preferred name for this new investment vehicle, a PIF, fearing that it was likely to cause confusion with a different financial product.

Following representations (see Table 3) the government responded with a further paper on Budget Day 2005. ${ }^{2}$ There were some really encouraging signs that progress was being made and the government had noted many of the points made in representations. No longer was the government to interfere in areas better dealt with through market forces, such as the type of property (eg hotels), the location of property and the form of management. Furthermore, a change of name from PIF to UK REIT received a universal welcome, and this change of approach was supported by a heartening statement by the Chancellor: 'The government continues to believe that tax reform in this area has the potential to improve the efficiency of the property market.'

Many different bodies, including those from the property and hotel industries, made representations. A summary of key representations is listed in Table 3, from which it is clear that there are still a number of areas which require discussion.

It is currently proposed that a UK REIT would be a limited company and could be listed or not listed on a public stock exchange. It is possible that it could be an open-ended vehicle. The property industry would prefer UK REITs to be unlisted (as well as listed) to ensure a flow of new vehicles into the marketplace.

The UK REIT would be required to carry on a ring-fenced property investment business where at least 75 per cent of the total gross income would be derived from ring-fenced activities (generating rental income) and at least 75 per cent of the assets

Table 2: The PIF matrix

What would a PIF achieve?

- The PIF would 'align the after-tax returns from holding property indirectly more closely to holding property directly'.

- The PIF structure would increase market efficiency in the residential and commercial sectors but would also focus on protection of investors' interests.

- Any reform should not lead to a reduction in the tax take for the Exchequer. 
Table 3: Representations - What has changed since 2004?

\begin{tabular}{|c|c|}
\hline What the government has been asked for & What did taxpayers get? \\
\hline Vehicle to be called a REIT & Yes \\
\hline A close-ended listed vehicle & Yes \\
\hline Other vehicles, eg unit trusts, could qualify for similar relief & Yes \\
\hline Unlisted vehicles & Still waiting to hear from the government \\
\hline $\begin{array}{l}\text { Does not suffer tax on its income if it meets certain } \\
\text { distribution requirements (retention to be sufficient to fund } \\
\text { maintenance of the assets) }\end{array}$ & Yes \\
\hline $\begin{array}{l}\text { Income distributed by the REIT to be subject to withholding } \\
\text { tax with the option of an application to receive income gross }\end{array}$ & Yes \\
\hline $\begin{array}{l}\text { Not subject to tax on gains if the proceeds were to be re- } \\
\text { invested }\end{array}$ & Yes \\
\hline $\begin{array}{l}\text { Could distribute gains if no suitable replacement investments } \\
\text { could be found }\end{array}$ & Yes \\
\hline Distributed gains to retain their character as gains & $\begin{array}{l}\text { No - distributed gains to be taxed as income but } \\
\text { not clear why }\end{array}$ \\
\hline $\begin{array}{l}\text { Issues such as whether management is internal or external etc } \\
\text { to be decided by the market not the government }\end{array}$ & Yes \\
\hline Gearing to be determined by the market & Under consideration by the government \\
\hline $\begin{array}{l}\text { REIT status given where investments are related to real } \\
\text { estate in the UK and EU, including investment in private } \\
\text { finance initiative projects, hotels etc }\end{array}$ & $\begin{array}{l}\text { Property in or outside the UK would qualify for } \\
\text { relief but no definitive statement on hotels, } \\
\text { shopping centres etc. }\end{array}$ \\
\hline $\begin{array}{l}\text { Income received should retain its characteristics in the tax } \\
\text { return of the investor }\end{array}$ & $\begin{array}{l}\text { Government concerned that UK investors would } \\
\text { be taxed on this basis but that offshore investors } \\
\text { would be treated as receiving dividends }\end{array}$ \\
\hline $\begin{array}{l}\text { Income or gains are only taxed where the investor is a } \\
\text { taxpayer }\end{array}$ & Yes \\
\hline An appropriate level of regulation to protect investors & Yes \\
\hline
\end{tabular}

would relate to the ring-fenced business. As yet it is not clear whether all or only some types of rental income would qualify as ring-fenced income. For example, turnover rents are common, so the expectation is that such rents would be ring-fenced income. But what about car parking or standard service charges (like security or maintenance costs)? Clearly these types of income are closely related to the letting of assets. It is too early to tell what would be included. Non-qualifying income is to be taxed at the appropriate rate for the vehicle (eg 30 per cent for a company).

There is to be no fetter on the type of property which a UK REIT could invest in. Qualifying investment property could be any type of real estate in any location, including outside the UK, so long as it is held for investment purposes. Therefore, it looks like a hotel could be a qualifying property so long as the income was derived from letting the complex to an operator and not derived from providing overnight accommodation or the use of conference facilities.

Current requirements are that the UK REIT must own more than one property, and no single property would exceed a yet to be agreed percentage of the ring-fenced assets. So turning to a 
shopping centre, how would this be viewed? Would it be treated as one asset (albeit multi-let) which could be qualifying property for a REIT? What about a residential block (again a single property, but with the prospect of reduced risk if there are many tenants)? One will have to wait for further government announcements.

The government has moved away from requiring internal management and will now let the market decide the appropriate management model for a REIT.

The UK REIT would be required to distribute at least 95 per cent of net ring-fenced income, which is currently to be determined by deducting relevant costs (management, maintenance, insurance, finance costs and capital allowances) from gross ring-fenced (rental) income. There would be a withholding tax of 22 per cent which would be levied at the time of the distribution. The rate has been fixed to reduce compliance costs for basic-rate taxpayers - their REIT income would be taxable at 22 per cent but the withholding tax would settle their liability and therefore they would not need to submit a tax return.

\section{TAXATION OF AN INVESTOR IN A REIT}

An investor in a REIT would be taxed on the distribution of ring-

\section{Taxation}

\section{Remaining areas of concern} fenced income as rent with a tax credit for withholding tax of 22 per cent. Other income distributed by the REIT would be taxed as dividend income. Therefore, for example, tax would not be payable on other income distributed to an investor which was a UK company, and individuals who were higher-rate taxpayers would pay tax at 32.5 per cent.

The government maintains that gains would not have to be distributed, but if distributed they would be taxed as income and not capital. It is not clear why HM Revenue and Customs (HMRC) does not want to maintain the underlying character of gains.

Shares in a REIT would be subject to stamp duty reserve tax (SDRT) (at 0.5 per cent) not stamp duty land tax (SDLT) (at 4 per cent).

\section{OTHER MATTERS}

In the discussion paper the government noted that there were some remaining areas of concern which it wished to discuss with the property industry. A small team, in which the author participated, was appointed by HM Treasury to explore these additional areas. The team included representative bodies of the property industry plus lawyers and the head of tax and accounting from a major listed property group. The team had a series of discussions with HMRC. Following consultation with the property industry, written representations were made to the government. One is waiting to hear what approach the government is to take on these issues.

There were essentially three areas - protection of the Exchequer where investors were not UK residents; gearing levels; and other issues such as groups. 


\section{Protection of tax take}

\section{Protection of the Exchequer's tax take}

The government was concerned that if it adopts a tax-exempt vehicle which withholds 22 per cent tax on distributions then those distributions may be treated as a dividend and not rent in the hands of an offshore investor. Consequently, treaty relief may reduce the tax take to 15 per cent or even zero. The counterargument is that an exempt vehicle is simple to operate and well understood by worldwide markets. While it is recognised that the tax take would be lower than 22 per cent it is still likely to be greater than tax currently paid by investors (for example, most of the top tier of quoted property companies suffer tax at lower rates than 15 per cent). Furthermore, if most of the investors are UK resident companies or individuals the tax would flow in from the investors. Consequently, it is difficult to understand the government's concerns. Currently, the government is being urged to apply the US model to existing treaties in order to protect its position.

Alternatives suggested have been a reduced tax rate of 22 per cent or lower (to bridge the gap between a treaty rate of 15 per cent and the usual rate of 22 per cent tax), or a trust structure where each investor owns shares which entitle him/her to direct receipt of rent and a dividend in relation to other income. The last alternative is complex in terms of legal and accounting issues. Consequently, any implementation would lead to significant delays.

Interestingly, the German tax authorities are currently advocating that a REIT structure similar to the preferred UK structure be adopted. While this is on hold pending their elections, press coverage indicates that Germany may be considering renegotiating treaties.

\section{Gearing}

The UK government wants to control gearing levels, since this is seen as a way to reduce the tax take because profits could be stripped out to non-UK companies which did not pay tax.

Experience in other jurisdictions demonstrates that the market determines gearing for the listed sector, but government should seek an arm's-length rate for the unlisted sector.

\section{Other issues}

Once the structure of a UK REIT is determined there are a whole series of other issues to consider. The government has sought consultation about groups, given that existing groups are likely to have activities which would not qualify for REIT status, eg trading in land. There may be more than one company in a group which does qualify but ownership of property has been separated between companies for commercial reasons, eg non-recourse finance, and there may be other non-qualifying activities in the group. In such circumstances transferring assets within the group may be expensive given the new SDLT restrictions on group relief. One proposal has 
been to use a regime that permits companies which carry on qualifying activities in a group to participate in a beneficial regime while the remainder of the companies are subject to the standard rate of tax.

The government has also been asked to allow innovative structures like the taxable REIT subsidiary (a company owned by a REIT which carries on trading and is subject to tax at standard rates). With the current focus on pension provisions, the government has been asked to consider allowing self-invested pension plans to hold shares in a UK REIT.

\section{CONVERSION CHARGE}

While the government sought consultation in 2004 on the conversion charge (how much and on what basis), there has been complete silence since then. Presumably, the government wants to sort out the structure first and then see what can be negotiated.

\section{THE PROSPECT FOR HOTELS}

If the government wants the UK to be able to compete with other jurisdictions then it should allow UK REITs to invest in hotels in one of two ways. First, a hotel could be just another asset class.

\section{Prospects for hotels} The REIT could be a passive landlord, merely investing in the land and building elements of a hotel with no interest in the operational side of the business. This would be no different than a REIT investing in offices, industrial buildings or providing retail units in a shopping centre. Rents could be related to turnover, which would be no different from turnover rents currently charged in shopping centres. One would expect that a UK REIT would be permitted to invest in hotels located throughout the world, although local taxes may mean that certain locations are not viable for UK investors.

An alternative framework could be based on a model used in the USA, where since 2001, given changes to the legislation (the REIT Modernization Act 1999), it has been possible for a REIT to participate indirectly in the underlying hotel business. There are legal, regulatory and tax issues to consider which are too detailed for this commentary, but the key principles are as follows. The US hotel REIT would buy a property and would then set up a taxable subsidiary that would lease the property from the REIT. Taxable REIT subsidiaries are not allowed to manage or operate hotels, so the taxable REIT subsidiary would contract out the management to a third party which is an experienced hotel operator. The taxable subsidiary would pay tax on its profit (which would be net of the hotel management fee) and could distribute some/all of the post-tax profit to the hotel REIT. The US hotel REIT would then receive the rental from the taxable subsidiary plus the dividend income that would be distributed to investors. With tough penalties for profit manipulation, the IRS also ensures that effective arm's-length pricing is used. 


\section{What is happening elsewhere}

Other jurisdictions, eg Australia (see Figure 1), have allowed business operations to be linked to the provision of accommodation, including stapling (where an investor acquires shares in a management company which are tied to the investment vehicle). If a similar structure were used in the UK and the operational vehicle were subject to tax at current rates, there would be no loss of revenue to the UK tax authorities, so such structures should be acceptable. Furthermore, the recent UK/UK transfer pricing provisions, that require transactions between such companies to be at arm's-length, would reinforce this.

Consequently, the industry should continue to press for hotels to be included as a qualifying investment for REITs.

\section{WHERE TO FROM HERE?}

The sad fact is that there is no pre-determined deadline for draft legislation for REITs. The government's discussion paper ends with the comment that if a workable solution can be reached then a UK REIT could be introduced in the Finance Bill in 2006. Is this really feasible? This will depend on how determined the government is to introduce the REIT.

One has seen many companies moving offshore as they try to provide collective investment schemes that are virtually transparent which then enable taxpayers and non-taxpayers to invest alongside each other. It would be interesting to know how much additional employment has been created outside the UK by these offshore moves in the past five years and what adverse impact there has been on the UK.

Figure I: Australia's hotel model

Australia's Listed Property Trust (LPT, REIT equivalent)

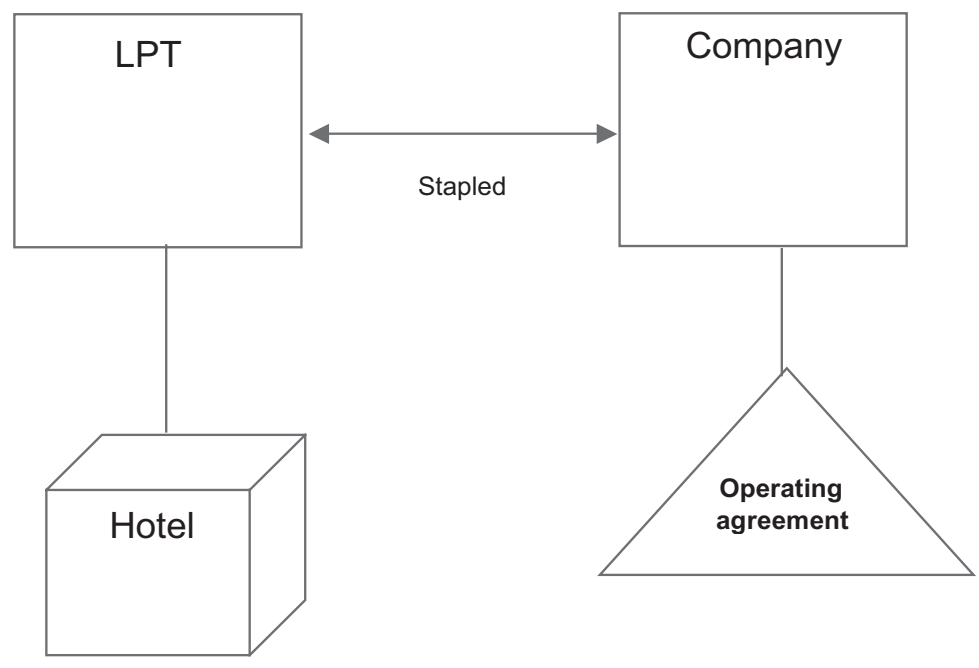

Key issue - rents must relate to turnover (not profits) to be eligible income 
Delay creates uncertainty
The government created renewed interest in REITs when it made encouraging statements in 2003. Was this led by the prospect of a windfall tax, given that the French authorities got half the capital gains tax (16.5 per cent) spread over four years as a conversion charge? The tone of both the discussion paper and the consultation document last year is very much about protecting the Exchequer. The emphasis seems throughout to be about potential loss, although this is difficult to comprehend given many investors are likely to be UK residents who would then be subject to tax on the income. It is more a question of a different group of taxpayers paying the tax (ie the investors, not the investment vehicle) rather than there being an absolute loss of tax. Where investors are offshore it should be noted that a combination of gearing, capital allowances and exemption from capital gains tax can quite often mean that the tax take for the Exchequer is very little.

The continuing delay in providing a REIT regime is creating uncertainty. If hotels want access to more finance or investors want hotels as an asset class then they will currently look offshore. Even if a REIT regime is introduced it will only work if the conversion price is right. For the moment, therefore, the UK has not joined the REIT club.

\section{Authors' note}

This paper has been prepared for general guidance on matters of interest only and does not constitute professional advice. Readers should not act upon the information contained in this paper without obtaining specific professional advice. No representation or warranty (express or implied) is given as to the accuracy or completeness of the information contained in this paper and, to the extent permitted by law, PricewaterhouseCoopers LLP, its members, employees and agents accept no liability and disclaim all responsibility for the consequences of readers or anyone else acting or refraining from acting in reliance on the information contained in this paper or for any decision based on it.

(C) Rosalind Rowe

\section{References}

1. HM Treasury/Inland Revenue (2004) Promoting More Flexible Investment in Property: A Consultation, TSO, London, UK.

2. HM Treasury/Inland Revenue (2005) UK Real Estate Investment Trusts: A Discussion Paper, TSO, London, UK. 